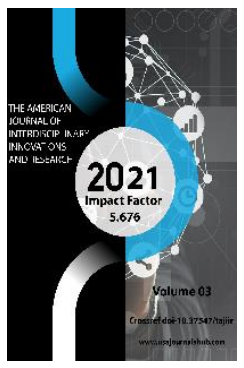

Copyright: Original content from this work may be used under the terms of the creative commons attributes 4.0 licence.

\section{Information Of The Educational Process And Education Of A Developed Generation}

\author{
Inoyatkhon Madimarovna Arzimatova \\ Candidate Of Philosophical Sciences, Associate Professor, Fergana State University, \\ Fergana, Uzbekistan \\ Jahongir Muminov \\ 3rd Year Student Faculty Of History Fergana State University, Fergana, Uzbekistan
}

\title{
ABSTRACT
}

The article deals with the process of informatization of the educational process, the actualization of education in the upbringing of a harmoniously developed generation, ensuring that its content meets the requirements of modern material and spiritual production, modern scientific knowledge.

\section{KEYWORDS}

Informatization, education, cultural development, educational crisis, humanitarianism, vocational education.

\section{INTRODUCTION}

No matter how complex the social problems that have arisen in the process of man-made civilization, humanity has not yet lost faith in the progress of science and science technology. Indeed, in recent years, the more rapid development of science as a social institution has begun to require special attention to all the factors that affect it. 


\section{MATERIALS AND METHODS}

As the President of the Republic of Uzbekistan Sh.M.Mirziyoev noted, "Today it is impossible to talk about modernization and renewal of the country, achieving sustainable development without the widespread development of information and communication technologies, the Internet" [1]. One of the factors influencing the development of science today is its informatization, without which there can be no scientific activity. It should also be noted that, "Humanity is entering a new era of evolutionary development. We are creating a new society. It is not just a changed society, but a whole new society. "[2] The problems associated with building this new society are often referred to as informatization, which forms a large area of research.

\section{RESULT AND DISCUSSION}

Information is an important resource for socioeconomic, technological and cultural development; the scale of its use is equal to the scale of the use of traditional resources. The money spent on information is of macroeconomic importance. The importance of information in the life of society is growing day by day. Methods of working with information are changing, the application of new information technologies is expanding.

The concept of information is widely used in everyday life. So everyone intuitively has an idea of what it is. However, when science begins to apply certain concepts in general, it clarifies these concepts, strictly limiting the use of terms to specific scientific circles. Ultimately, the concept of information becomes the subject of research in many disciplines and is generalized in each of them. The concept of information has become one of the most important areas of modern science.

The need to effectively address the challenges facing life, as well as the internal needs of science, required the informatization of science. It is necessary to actualize education, to ensure that the content of education meets the requirements of modern material and spiritual production, modern scientific knowledge. In this regard, it is necessary to increase the weight of theoretical sciences, especially mathematics, which are necessary for the effective use of information technology. Consolidation of knowledge using new, including computer forms of knowledge recording, prioritizing problem solving rather than memorizing knowledge, thinking, teaching independent learning, changing forms and methods of teaching, developing students' creative abilities - all this is part of the modern education system. enters the process of radical change.

Creating a system of continuing education is an important component of the aforementioned process. This education system should cover all stages of human life. The system of continuing education is characterized by the diversity of its forms and methods. Its task is to develop the mental and physical abilities of the individual. The system of continuing education is now being gradually formed, its main features and stages are being determined. In particular, the stages of continuing education include pre-school education, general education, vocational training at various levels, education of the population during active employment, training of pensioners and nonworking family members. Thus, education covers all stages of a person's life, ensuring that his knowledge and skills are constantly updated and replenished.

The current trends in education are the opposite - the growth of the role of education in the life and work of society and the crisis in education. This crisis is explained not only by the financial deficit, but also by the fact that the education system, which effectively serves the industrial society, does not meet the requirements of the information society. Indeed, education plays a completely different role in the information society. D. It is no 
coincidence that Bell described universities in his concept of a future society as "an important institution of postindustrial society". The sociology of education that has emerged in recent years is S. Lipset, R. Nisbet, J. In the person of Furaste and others, the education system hopes to rebuild today's society from within.

While discussing the different perspectives on the nature of the crisis in education and ways out of it, we can note two main approaches to these problems. The first approach is technocratic. He argues that the emerging information society requires new thinking, the formation of a new type of attitude to the rapidly changing information and technical being. This requires that the content and methodology of education be focused on the formation of students' skills of rational work with information, knowledge of computer technology, professional-pragmatic thinking. The second approach to overcoming the crisis prevailing in the current education system can be called a humanitarian approach. He sees the causes and content of the crisis in the inhumanity of education, when it has become a tool of industrial and market relations. From the point of view of this concept, education loses its humanity under the influence of industrial technocratism and market utilitarianism, and becomes an interest-based teaching of narrow professional knowledge and skills.

Reforming the education system involves not only updating the content of education, creating streams of educational information, introducing completely new forms of distribution and integration of pedagogical work, but also humanizing and computerizing education. " Today, new humanistic values, traditional humanities are being introduced in the education system "[3].

In general, "Technical education aimed at the development of the human person, his abilities and needs cannot be called inhumane education. Technical activity is the humanization of the individual, in which it is a factor in the development of an active creative attitude to the world "[4]. The influence of external factors on the education system, which shape the standards of technical expertise, has led to the inhumanization of engineering education, in which technocratism has become too extreme. The stagnation of the achievements of science and technology, the focus on practical and technical usefulness, the over-ideologicalization of the social sciences have led to the over-technicalization of education. The educational process in the technical university is focused on the formation of a specialist in a narrow field. The tendency to subordinate education to market relations also played a significant role in this. However, it turns education into a means of surviving or succeeding in a market economy, and an educated person into a commodity.

\section{CONCLUSION}

Thus, the inhumanity of education is objectively determined by the development of science and technology and socio-economic conditions. The shortcomings of engineering education are manifested when society is confronted with the scientific and technological challenges posed by the development of general theory of cybernetics and systems, automation and robotics, computer science and synergetics, genetics and biotechnology. Shortcomings and shortcomings in the system of training engineers have become apparent, first of all, in the imperfection of its social component in terms of content and teaching method.

The information society technology not only imposes certain requirements on the educational process, but also equips the process with modern media capable of providing direct and feedback between teacher and student. The role of computers in the educational process is so great that in the future it is thought that electronic machines 
will completely replace teachers and make their tasks cheaper, more efficient and more efficient. Contrary to popular belief, the use of computers in education has negative consequences, such as formalizing knowledge, depriving the teacher of live emotional contact with the student, and the computerization of education leads to its standardization and unemployment among teachers. This is the opinion of persistent-minded teachers, and it is not new, because news in the field of education has always met with opposition, even from enlightened people. For example, the great philosopher and educator Socrates once considered oral speech to be the most rational method of education and upbringing, and was very negative about the use of writing in education, which impedes people's memory, as oral speech better expresses the meaning of thoughts than written speech.

In conclusion, the study of economic and historical, social and informational and other aspects of education has become relevant in the activities of many state and international organizations in the late twentieth century. The ongoing reforms and modernization processes in our society require a new restructuring of the state education policy in the XXI century. The task of forming in future professionals a culture of worldview and universal, spiritual values and a sense of personal responsibility, the ability to think independently, the ability to clearly define future goals and objectives is of paramount importance. The informatization of education is becoming a requirement of the time to direct it to a new, holistic understanding of the world.

\section{REFERENCES}

1. Мирзиёев Ш.М. Миллий тараққиёт йўлимизни қатъият билан давом эттириб, янги босқичга кўтарамиз. Т."Ўзбекистон", 2017, 86 бет.
2. Тоффлер Э. Шок будущего. -М: АСТ, 2001, C- 669.

3. Қурбонов Ш., Сейтхалилов Э. Ответственность образования в предупреждение и преодоление вызовов современности. -Т.: 2003 Алимова Д. Инсоният тарихи ғоя ва мафкуралар тарихидир. -Т.: 2001. Назаров Қ. Қадриятлар фалсафаси. - Т.: Университет, 2004. Қувватов Н. Ўтиш даври тафаккури. -Т.: 2002.

4. Шубас А.К. Социальное реагирование на информацию. -Т.: Узбекистан, 1993, С-45.

5. Madimarovna, A. I., \& Khoshimovich, M. B. (2020). Factors for the development of tourism culture in the uzbek national value system. ACADEMICIA: An International Multidisciplinary Research Journal, 10(4), 575-580.

6. Madimarovna, A. I. (2020). The Role of Art in Youth's Aesthetic Education. CrossCultural Communication, 16(1), 121-123.

7. Arzimatova, I. (2019). AESTHETIC EDUCATION, ITS FEATURES AND STRUCTURE. Scientific Bulletin of Namangan State University, 1(6), 219-222.

8. Arzimatova, I. (2019). Art industry development of society and society culture. Scientific Bulletin of Namangan State University, 1(1), 129-134.

9. Арзиматова, И. М. (2020). Искусство как своеобразное средство воспитания. Вестник педагогики: наука и практика, (51), 116-117.

10. Арзиматова, И., \& Муминов, Ж. (2019). Роль и значение эстетической морали в процессе совершенствования молодого поколения. ББК 60 о 23, 60.

11. Арзиматова, И., \& Муминов, Ж. (2019). Секция «Философские Науки». ББК $60 \mathrm{~A}$ 43, 234.

12. Арзиматова, И. М. (2016). К вопросу о созидательном потенциале национальной эстетической культуры в гражданском обществе. Молодой ученый, (3), 1112-1114. 
13. Арзиматова, И. М. (2019). Процесс глобализации и формирование чувства патриотизма у молодёжи. in перспективные области развития науки и технологий (рр. 20-22).

14. Arzimatova, I. M. (2021). Relationship Of Aesthetic Culture And Spirituality Of Personality. The American Journal of Applied sciences, 3(02), 100-104.

15. Arzimatova, I., \& Tursunov, B. (2021). THE ROLE SOCIAL FACTORS IN THE SPIRITUAL DEVELOPMENT PERSONALITY. Scientific Bulletin of Namangan State University, 2(2), 163-170.

16. Arzimatova, I. M., \& Muminov, D. (2020). Classification Of Modern Aesthetic Problems. The American Journal of Social Science and Education Innovations, 2(11), 496-500.

17. Arzimatova, I. A. AESTHETICAL ESSENCE OF LABOR IN PERSONAL DEVELOPMENT.

18. Arzimatova, I. M. (2020). Art as a kind of education. Bulletin of Pedagogy: Science and Practice,(51), 116-117.

19. Arzimatova, I., \& Muminov, J. (2019). Role and significance of aesthetic morality in the process of improving young generation.

20. Arzimatova, I. M. (2019). Globalization process and formation of sense of patriotism in young people. prospective sciences and technologies, 20-22.

21. Arzimatova, I., \& Muminov, j. (2019). Section" philosophical sciences.

22. Arzimatova, I. M. (2016). On the question of the creative potential of the national aesthetic culture in civil society. Young Scientist,(3), 1112-1114.

23. Madimarovna, A. I., \& Madaminovich, M. J. (2020, December). THE PLACE OF AESTHETIC AND ARTISTIC CULTURE IN THE SPIRITUAL LIFE OF SOCIETY AND THE INDIVIDUAL. In Archive of Conferences (Vol. 10, No. 1, pp. 177-178).

24. Арзиматова, И. М. (2019). Социальнопсихологические особенности национальной эстетической культуры. In
Условия социально-экономического развития общества: история и современность (рр. 9-12).

25. Арзиматова, И., \& Муминов, Ж. (2019). Взаимосвязь экологического и эстетического образования. in актуальные вопросы развития современной науки и образования (рp. 234-236).

26. Ahmadjonovna, E. T., \& Bakhromovich, S. I. (2020). Pedagogical Analysis Of CulturoEducational Institutions' Actions In Youth Education (On The Example Of Museum Activities). The American Journal of Social Science and Education Innovations, 2(08), 576-582.

27. Bakhromovich, S. I. (2020). Effects of Objective and Subjective Factors to Develop Intellectual Culture of Youth. Canadian Social Science, 16(2), 55-59.

28. Сиддиков, И. Б. (2018). Социальнофилософские аспекты формирования интеллектуальной культуры молодёжи. Theoretical \& Applied Science, (1), 61-66.

29. Bakhromovich, S. I. (2020). Analysis of modern approaches to ensuring the effectiveness of management in higher education institutions. the american journal of social science and education innovations, 2(12), 364-369.

30. Bakhromovich, S. I. (2018). Social and philisophical performance of making youth's intellectual culture. European science review, (7-8).

31. Siddikov, I., \& Gulomov, A. (2020). Philosophical and psychological features of the formation of asertive behavior in the development of cognitive activity. In Психологическое здоровье населения как важный фактор обеспечения процветания общества (pp. 38-42).

$\begin{array}{llr}\text { 32. СИДДИКОВ, И. } & \text { Б. (2019). } \\ \text { ГОСУДАРСТВЕННАЯ } \\ \text { ОТНОШЕНИИ } \\ \text { МОЛОДЕЖИ } & \text { В } \\ \text { УЗБЕКИСТАНЕ: НАЦИОНАЛЬНЫЙ ОПЫТ } \\ \text { И РЕАЛЬНАЯ } & \text { НЕОБХОДИМОСТЬ } \\ \text { МЕЖДУНАРОДНЫХ } & \text { ИНИЦИАТИВ. In }\end{array}$


Условия социально-экономического

развития общества: история и современность (pp. 38-43).

33. Bakhromovich, S. I. Development trends and transformation processes in academic mobility in higher education in uzbekistan and the world.

34. Mirzarahimov, B. H. (2020). The Tasks Of Tourism In Aesthetic Education: The Harmony Of Historicity And Modernity. The American Journal of Social Science and Education Innovations, 2(09), 652658.

35. Mirzarahimov, B. (2019). The factor of good neighborhood and tourism development (Philosophical analysis). Scientific Bulletin of Namangan State University, 1(1), 140-145.

36. Mirzarakhimov, B. (2020). Tourism-is a modern means of aesthetic education. Вестник педагогики: наука и практика, (51), 135-136.

37. Мирзарахимов, Б. Х. (2019). Культура туризма как стратегия развития книговедения. in перспективные области развития науки и технологий (pp. 57-58). 